JURNAL चEEKNOSAINS

\begin{tabular}{lll}
\hline VOLUME 5 & No. 1, 22 Desember 2015 Halaman 1-80
\end{tabular}

\title{
ANALISIS KEBUTUHAN DAN KETERSEDIAAN AIR DI DAS KEDUANG JAWA TENGAH
}

\author{
Erlynda Kumalajati \\ Balai Pendidikan dan Pelatihan Kehutanan Kupang \\ Email: e.kumalajati@gmail.com \\ Sambas Sabarnudi dan Budiadi \\ Program Studi Ilmu Kehutanan, Fakultas Kehutanan \\ Universitas Gadjah Mada \\ Putu Sudira \\ Program Studi Teknik Pertanian, Fakultas Teknologi Pertanian \\ Universitas Gadjah Mada
}

\begin{abstract}
This study aims to examine the balance between the availability and water need in the present and the future in Keduang Watershed, Central Java. The water need is calculated by using the standard water need for irrigation and non-irrigation. Types of non-irrigation water need encompass the water need for domestic, office, and the facilities of health, education, religious duties, industry, and market, as well as livestock. The standard water need is from SNI 19-6728.1-2002 and Planning Criteria of Directorate General of Human Settlements of Department of Public Works in 1996. This study uses socio-economic data in 2013. The availability of water is calculated by using Soil Conservation Service Curve Number (SCS CN) from USDA with the hydrological data from 2005 to 2013. This study uses data in 2013, due to the limitations of the data that can be obtained. In the analysis of availability and water need, hydrological, and spatial data are projected until 2033 and analyzed using quantitative analysis in the form of descriptive statistics. The result shows that 1) from year to year in Keduang watershed, the water need is increasing with an average increase of $3.38 \%$, while the water availability is decreasing with an average decrease of $0.09 \%$. 2) Water deficit will begin in 2023, when the water need is reaching $115,306,568.00 \mathrm{~m}^{3} /$ year, whereas the water availability only $112,250,656.00 \mathrm{~m}^{3} /$ year. From this calculation, it can be concluded that if there is no effort to change the trend of land cover that lead to the goal of water conservation, then, the water availability will not able to cover the water need. Thus, in the future, Keduang watershed will occur water deficit.
\end{abstract}

Keywords: SCS CN; Water availability; Water need; Watershed

\begin{abstract}
ABSTRAK
Penelitian ini bertujuan untuk mengkaji kesetimbangan antara kebutuhan dan ketersediaan air pada saat ini dan masa mendatang di Daerah Aliran Sungai (DAS) Keduang, Jawa Tengah. Kebutuhan air dihitung dengan menggunakan standar kebutuhan air untuk jenis kebutuhan irigasi dan non irigasi. Jenis kebutuhan air untuk non irigasi meliputi kebutuhan air untuk domestik, perkantoran, fasilitas kesehatan, fasilitas pendidikan, fasilitas peribadatan, industri, dan pasar, serta peternakan. Standar kebutuhan air yang digunakan adalah SNI 19-6728.1-2002 dan Kriteria Perencanaan Ditjen Cipta Karya Dinas PU tahun 1996. Data sosial ekonomi yang dipergunakan adalah data tahun 2013. Ketersediaan air dihitung dengan menggunakan metode Soil Conservation Service Curve Number (SCS CN) dari USDA dengan data hidrologi dari tahun 2005 sampai dengan 2013. Penggunaan data tahun 2013 dikarenakan adanya keterbatasan data yang dapat diperoleh. Dalam analisis ketersediaan dan kebutuhan air, data hidrologi dan spasial diproyeksikan sampai dengan tahun 2033 dan dianalisis dengan menggunakan analisis kuantitatif berupa statistik deskriptif. Hasil penelitian menunjukkan bahwa 1) dari tahun ke tahun kebutuhan air di DAS Keduang semakin bertambah dengan rata-rata penambahan 3,38\%,
\end{abstract}


sedangkan ketersediaan airnya semakin berkurang dengan rata-rata pengurangan 0,09\%. 2) Defisit air mulai terjadi pada tahun $2023 \mathrm{di}$ mana kebutuhan air mencapai 115.306.568,00 m³ tahun, sedangkan ketersediaan air hanya sebesar 112.250.656,00 $\mathrm{m}^{3}$ /tahun. Dari hasil perhitungan tersebut, dapat disimpulkan bahwa apabila tidak ada upaya untuk mengubah kecenderungan perubahan penutupan lahan yang sedang terjadi ke arah tujuan konservasi air maka ketersediaan air tidak akan mencukupi kebutuhannya sehingga di masa mendatang DAS Keduang akan mengalami defisit air.

Kata Kunci: DAS; Kebutuhan air; Ketersediaan air; SCS CN.

\section{PENGANTAR}

Sumberdaya air merupakan sumberdaya yang vital bagi kehidupan makhluk hidup di Bumi karena ketersediaan air memerlukan sifat kelanggengan untuk dapat dipergunakan antargenerasi. Sifat kelanggengan air memerlukan pengelolaan yang tepat dan berkaitan dengan distribusinya. Kerusakan daerah aliran sungai (DAS) lebih banyak disebabkan oleh faktor nonalami, yaitu perilaku manusia. Bertambahnya populasi penduduk menyebabkan terjadinya konversi lahan untuk memenuhi kebutuhan kebutuhan sehari-hari dan pemukiman tanpa memperhatikan faktor lingkungan. Kegiatan tata guna lahan yang bersifat mengubah bentang lahan dalam suatu DAS seringkali dapat mempengaruhi hasil air (Asdak, 2007).

DAS Keduang merupakan salah DAS yang dinyatakan dalam kondisi kritis oleh pemerintah. Menurut JICA (2007), DAS ini merupakan penyumbang terbesar sedimentasi yang terjadi di Waduk Gajah Mungkur, tempat aliran sungainya bermuara. Sutrisno (2011) menyatakan bahwa telah terjadi konversi atau perubahan penggunaan lahan yang nyata di wilayah Sub DAS Keduang, antara tahun 1993 sampai dengan 2008. Beberapa penggunaan lahan beralih menjadi penggunaan lahan lainnya. Terjadinya perubahan tata guna lahan dan jenis vegetasi dalam skala besar yang bersifat permanen dapat mempengaruhi besar kecilnya hasil air (Asdak, 2007). Besar kecilnya hasil air ini akan mempengaruhi tingkat pemenuhan ketersediaan air yang dibutuhkan oleh masyarakat setempat. Oleh karena itu, studi ini fokus untuk mengetahui kebutuhan dan berapa lama ketersediaan air Das Kaduang untuk beberapa puluh tahun ke depan.

Kajian ini berlokasi di DAS Keduang, sehingga secara geografis, lokasi yang digunakan untuk perhitungan kebutuhan airnya hanya sebatas pada kecamatankecamatan dan/atau desa-desa yang terletak di wilayah DAS Keduang. Secara administratif, DAS Keduang masuk dalam dua kabupaten, yaitu Kabupaten Wonogiri dan Karanganyar. Kecamatan di DAS Keduang yang termasuk dalam Kabupaten Wonogiri adalah Slogohimo, Jatipurno, Jatisrono, Jatiroto, Girimarto, Sidoharjo, Ngadipiro, Nguntoronadi, dan Wonogiri. Khusus untuk Kecamatan Wonogiri, hanya desa Pokoh Kidul (kecuali dusun Petir) yang masuk dalam wilayah DAS Keduang. Kecamatan di DAS Keduang, yang masuk dalam Kabupaten Karanganyar adalah Kecamatan Jatiyoso, khususnya Desa Wonokeling dan Wonorejo.

\section{Metode}

Untuk menghitung kebutuhan air di DAS Keduang, standar dan rumus-rumus yang digunakan berdasarkan pada SNI 196728.1-2002 (Bandan Standarisasi Nasional, 2002) dan Kriteria Perencanaan Ditjen Cipta Karya (Dinas Pekerjaan Umum, 1996) dengan Tabel standar kebutuhan air untuk masingmasing kepentingan dapat dilihat pada Tabel 1. Data sosial dan ekonominya diperoleh dari BPS untuk tahun 2013. Kebutuhan air yang dihitung meliputi kebutuhan air untuk domestik, fasilitas kesehatan, fasilitas pendidikan, fasilitas peribadatan, perkantoran, industri, pasar, pertokoan, dan peternakan serta irigasi.

Kebutuhan air domestik dihitung dengan menggunakan standar kebutuhan air konsumsi di pedesaan sebesar 100 lt/hari dan rumus sebagai berikut:

$\mathrm{Qd}=365$ hari $\times[\mathrm{q}(\mathrm{r}) \times 1 / 1000 \times \mathrm{P}(\mathrm{r})] \ldots \ldots \ldots$ (1) 
dengan Qd adalah konsumsi air domestik $\left(\mathrm{m}^{3} /\right.$ tahun), $\mathrm{q}(\mathrm{r})$ adalah konsumsi air per kapita (liter/kapita/hari), dan P(r) adalah jumlah penduduk (jiwa).

Kebutuhan air untuk fasilitas kesehatan dihitung dengan menggunakan standar kebutuhan sebesar 200 liter/unit/hari untuk puskesmas dan sebesar 2000 liter/tempat tidur/hari untuk rumah bersalin dengan rumus sebagai berikut:

Qs (puskemas) $=\sum$ unit $\times 365$ hari $\times \mathrm{q}(\mathrm{sp}) / 1000(2)$

Qs $(\mathrm{RSB} / \mathrm{RB})=\Sigma$ bed $\times 365$ hari $\times \mathrm{q}(\mathrm{srsb}) / 1000$... (3)

$\mathrm{Qs}=\mathrm{Qs}$ (puskemas) + Qs (RSB/RB)

dengan Qs adalah konsumsi air untuk fasilitas kesehatan ( $\mathrm{m}^{3} /$ tahun), Qs (puskemas) adalah konsumsi air untuk fasilitas kesehatan puskesmas ( $\mathrm{m}^{3} /$ tahun), Qs (RSB/RB) adalah konsumsi air untuk fasilitas kesehatan rumah sakit bersalin $\left(\mathrm{m}^{3} /\right.$ tahun), $\mathrm{q}(\mathrm{sp})$ adalah konsumsi air per unit puskesmas (liter/unit/ hari), dan q (srsb) adalah konsumsi air perunit rumah sakit bersalin (liter/bed/hari).

Kebutuhan air untuk fasilitas pendidikan dihitung dengan asumsi bahwa jumlah hari libur dalam satu tahun sebanyak 22 hari libur nasional, 48 hari libur mingguan, dan 29 hari libur semester. Standar kebutuhan air sebesar 10 liter/murid/hari. Rumus perhitungannya adalah sebagai berikut:

Qp $=\Sigma$ murid $\times q(p) / 1000 \times(365-\Sigma$ hari libur $)$

dengan $\mathrm{Qp}$ adalah konsumsi air untuk fasilitas pendidikan $\left(\mathrm{m}^{3} /\right.$ tahun) dan $\mathrm{q}(\mathrm{p})$ adalah standar konsumsi air per murid sebesar (liter/murid/hari).

Kebutuhan air untuk fasilitas peribadatan dihitung dengan rumus sebagai berikut:

$\mathrm{Qib}(\mathrm{mas})=\Sigma$ masjid $\times 365$ hari $\times \mathrm{q}$

(ibmas)/1000

Qib(mus) $=\Sigma$ mushola $\times 365$ hari $\times \mathrm{q}$

(ibmus)/1000

Qib $=$ Qib(mas) + Qib(mus) dengan Qib adalah konsumsi air untuk fasilitas peribadatan $\left(\mathrm{m}^{3} /\right.$ tahun), Qib (mas) adalah konsumsi air masjid ( $\mathrm{m}^{3} /$ tahun), Qib (mus) adalah konsumsi air mushola $\left(\mathrm{m}^{3} /\right.$ tahun), q (ibmas) adalah standar konsumsi air masjid (liter/unit/hari), dan q (ibmus) adalah standar konsumsi air mushola (liter/ unit/hari).

Kebutuhan air untuk perkantoran dihitung dengan asumsi bahwa jumlah hari libur dalam 1 tahun sebanyak 22 hari libur nasional dan 96 hari libur mingguan.

Qk $=\Sigma$ pegawai $\times \mathrm{q}(\mathrm{k}) / 1000 \times(365-\Sigma$ hari

libur)

dengan Qk adalah konsumsi air untuk fasilitas perkantoran $\left(\mathrm{m}^{3} /\right.$ tahun) dan $\mathrm{q}(\mathrm{k})$ adalah standar konsumsi air perkantoran (liter/pegawai/hari).

Kebutuhan air untuk industri, pasar, dan pertokoan dihitung dengan asumsi bahwa jumlah hari libur dalam satu tahun untuk pegawai industri sebanyak 22 hari libur nasional dan 48 hari libur mingguan (6 hari kerja per minggu), sedangkan untuk toko, warung makan, dan pasar (Karanganyar) yang tidak ada keterangan jumlah kursi dan pegawainya diasumsikan mempunyai dua pegawai per-toko, 20 kursi per-warung makan, dan luas pasar sebesar rata-rata luas pasar di Wonogiri. Rumus-rumus yang dipergunakan adalah sebagai berikut:

Qid-ind $=(365-\Sigma$ hari libur $) \times \Sigma$ industri $\times$ $\mathrm{q}$ (id-ind) $/ 1000 \times(3600 \times 24)$

Qid-psr $=365$ hari $\times$ luas pasar $\times \mathrm{q}$ (idpsr)/1000

Qid-toko $=365$ hari $\times \Sigma$ pegawai $\times \mathrm{q}(\mathrm{id}-$ toko) $/ 1000$

Qid-wm $=365$ hari $\times \Sigma$ kursi $\times$ q(idwm) $/ 1000$

dengan Qid-ind adalah konsumsi air untuk industri ( $\mathrm{m}^{3} /$ tahun), Qid-psr adalah konsumsi air untuk pasar ( $\mathrm{m}^{3} /$ tahun), Qidtoko adalah konsumsi air untuk toko $\left(\mathrm{m}^{3} /\right.$ tahun), Qid-wm adalah konsumsi air untuk warung makan ( $\mathrm{m}^{3} /$ tahun), $\mathrm{q}$ (id-ind) adalah 
standar konsumsi air industri (liter/detik/ hari), q (id-psr) adalah standar konsumsi air pasar (lt/hektar/hari), dan q (id-wm) adalah standar konsumsi air warung makan (liter/ kursi/hari).

Kebutuhan air untuk peternakan dihitung dengan rumus sebagai berikut:

Qpt $=365$ hari $\times\{q(c / b) \times P(c / b)+q(s / g)$

$x \mathrm{P}(\mathrm{s} / \mathrm{g})+\mathrm{q}(\mathrm{pi}) \times \mathrm{P}(\mathrm{pi})+\mathrm{q}(\mathrm{po}) \times \mathrm{P}(\mathrm{po})\}$

dengan Qpt adalah konsumsi air untuk ternak $\left(\mathrm{m}^{3} /\right.$ tahun), $\mathrm{q}(\mathrm{c} / \mathrm{b})$ adalah standar konsumsi air sapi/kerbau (liter/ekor/hari), $\mathrm{P}(\mathrm{c} / \mathrm{b})$ adalah jumlah sapi/kerbau (ekor), $\mathrm{q}$ (s/g) adalah standar konsumsi air domba/ kambing (liter/ekor/hari), P (s/g) adalah jumlah domba/kambing (ekor), q(pi) adalah standar konsumsi air babi (liter/ekor/hari), P (pi) adalah jumlah babi (ekor), q (po) adalah standar konsumsi air unggas (liter/ekor/ hari), dan $\mathrm{P}$ (po) adalah jumlah unggas (ekor). Kebutuhan air untuk irigasi dihitung dengan rumus sebagai berikut:

$\mathrm{Qi}=\mathrm{A} \times(\mathrm{q}(\mathrm{i}) / 1000) \times \mathrm{Tn} \times(3600 \times 24)$

dengan Qi adalah konsumsi air untuk irigasi ( $\mathrm{m}^{3} /$ tahun), q(i) adalah standar konsumsi air untuk irigasi (liter/detik/ha), dan Tn adalah jumlah hari irigasi (asumsi 4 bulan).

Kebutuhan total di DAS Keduang adalah sebagai berikut:

$\mathrm{Qtot}=\mathrm{Qd}+\mathrm{Qs}+\mathrm{Qp}+\mathrm{Qib}+\mathrm{Qk}+\mathrm{Qid}+$

Qpt + Qi

Tabel 1

Standar Kebutuhan Air Untuk Masing-Masing Kepentingan yang Dipakai Pada Penelitian Ini

\begin{tabular}{|c|c|c|c|}
\hline No. & Jenis kepentingan & Standar kebutuhan air & Satuan \\
\hline 1 & Domestik & 60 & lt/kapita/hari \\
\hline 2 & $\begin{array}{l}\text { Kesehatan : - puskemas } \\
\text { - RS bersalin }\end{array}$ & $\begin{array}{l}2.000 \\
200 \\
\end{array}$ & $\begin{array}{l}\text { 1t/unit/hari } \\
\text { lt/bed/hari }\end{array}$ \\
\hline 3 & Pendidikan & 10 & lt/murid/hari \\
\hline 4 & $\begin{array}{l}\text { Peribadatan : - masjid } \\
\text { - mushola }\end{array}$ & $\begin{array}{l}3.000 \\
2.000\end{array}$ & $\begin{array}{l}\text { lt/unit/hari } \\
\text { lt/unit/hari }\end{array}$ \\
\hline 5 & Perkantoran & 10 & lt/pegawai/hari \\
\hline 6 & $\begin{array}{l}\text { Industri, pasar, dan pertokoan : } \\
\text { - industri } \\
\text { - toko } \\
\text { - pasar } \\
\text { - warung makan }\end{array}$ & $\begin{array}{l}10 \\
10 \\
12.000 \\
100 \\
\end{array}$ & $\begin{array}{l}\text { lt/ hari } \\
\text { lt/pegawai/hari } \\
\text { lt/hektar/hari } \\
\text { lt/tempat duduk/hari }\end{array}$ \\
\hline 7 & $\begin{array}{l}\text { Peternakan : - sapi/kerbau } \\
\text { - domba/kambing } \\
\text { - babi } \\
\text { - unggas }\end{array}$ & $\begin{array}{l}40 \\
5 \\
6 \\
0.6 \\
\end{array}$ & $\begin{array}{l}\text { lt/ekor/hari } \\
\text { lt/ekor/hari } \\
\text { lt/ekor/hari } \\
\text { lt/ekor/hari }\end{array}$ \\
\hline 8 & Irigasi & 1 & lt/det/ha \\
\hline
\end{tabular}

Ketersediaan air di DAS Keduang dihitung dengan menggunakan metode SCS $\mathrm{CN}$ yang dikembangkan oleh USDA dengan data yang dipergunakan adalah data dari tahun 2005 sampai dengan 2013. Berikut ini adalah rumus untuk memperoleh volume debit permukaan (USDA, 1988):

$\mathrm{Q}=\frac{(\mathrm{P}-0,2 \mathrm{~S})^{2}}{(\mathrm{P}+0,8 \mathrm{~S})}$

dengan $\mathrm{Q}$ adalah debit permukaan $(\mathrm{mm}), \mathrm{P}$ adalah curah hujan harian maksimum (mm), dan $\mathrm{S}$ adalah retensi potensial maksimum $(\mathrm{mm})$. Besarnya $\mathrm{S}$ diperoleh dari rumus berikut ini.

$\mathrm{S}=\frac{25400}{\mathrm{CN}}-254$

Nilai $\mathrm{CN}$ bervariasi dan tergantung pada penggunaan lahan, jenis hidrologi tanah, dan Antecedent Moisture Condition (AMC). Kelompok hidrologi tanah dapat dilihat pada Tabel 2. 
ERLYNDA KUMALAJATI, SAMBAS SABARNUDI, BUDIADI, DAN PUTU SUDIRA ANALISIS

KEBUTUHAN DAN KETERSEDIAAN AIR DI DAS KEDUANG JAWA TENGAH

Tabel 2

Kelompok Hidrologi Tanah Untuk Kondisi AMC II (US USDA, 1972)

\begin{tabular}{lll}
\hline $\begin{array}{c}\text { Kelompok } \\
\text { tanah }\end{array}$ & \multicolumn{1}{c}{ Keterangan } & $\begin{array}{c}\text { Laju infiltrasi } \\
\text { (mm/jam) }\end{array}$ \\
\hline $\mathrm{A}$ & $\begin{array}{l}\text { Potensi air larian paling kecil, termasuk tanah pasir dalam dengan unsur } \\
\text { debu dan liat. Laju infiltrasi tinggi }\end{array}$ & $8-12$ \\
\hline $\mathrm{B}$ & $\begin{array}{l}\text { Potensi air larian kecil, termasuk tanah pasir lebih dangkal dari A. } \\
\text { Tektur halus sampai sedang. Laju infiltrasi sedang. }\end{array}$ & $4-8$ \\
\hline $\mathrm{C}$ & $\begin{array}{l}\text { Potensi air larian sedang, tanah dangkal dan mengandung cukup liat. } \\
\text { Tektur sedang sampai halus. Laju infiltrasi rendah. }\end{array}$ & $1-4$ \\
\hline $\mathrm{D}$ & $\begin{array}{l}\text { Potensi air larian tinggi, kebanyakan tanah liat, dangkal dengan lapisan } \\
\text { kedap air dekat permukaan tanah. Laju infiltrasi rendah. }\end{array}$ & $0-1$ \\
\hline
\end{tabular}

Kriteria pengelompokan AMC yang dibagi menjadi tiga kelas, yaitu AMC I yang mewakili kondisi tanah kering, AMC II yang mewakili kondisi tanah normal, dan AMC III yang mewakili kondisi tanah basah, dapat dilihat pada Tabel 3.

Tabel 3

Kriteria Untuk Masing-Masing Kelas AMC Kelas Jumlah hujan selama 5 hari terdahulu AMC (mm)

\begin{tabular}{lll}
\cline { 2 - 3 } & \multicolumn{1}{c}{ Musim berau } & \multicolumn{1}{c}{ Musim tanam } \\
\hline I & $<13$ & $<36$ \\
\hline II & $13-28$ & $36-53$ \\
\hline III & $\geq 28$ & $\geq 53$ \\
\hline
\end{tabular}

Jumlah hujan selama lima hari terdahulu dihitung berdasarkan indeks jumlah hujan selama lima hari terdahulunya dengan rumus yang dijelaskan oleh Kovar (1990).

$\mathrm{API}_{5}=\sum_{\mathrm{T}=1}^{5}\left(\mathrm{P}_{\mathrm{T}} \mathrm{C}^{\mathrm{T}-1}\right)$

dengan $\mathrm{API}_{5}$ adalah indeks jumlah hujan selama lima hari sebelumnya atau five days antecedent precipitation index $(\mathrm{mm}), \mathrm{P}_{\mathrm{T}}$ adalah hujan 5 hari sebelumnya atau five days antecedent precipitation index ( $\mathrm{mm})$, dan $\mathrm{C}^{\mathrm{T}-1}$ adalah konstanta evapotranspirasi yang bernilai 0,93 .

\section{HASIL DAN PEMBAHASAN}

\section{Kebutuhan Air}

Kebutuhan air untuk domestik dihitung berdasarkan jumlah penduduk pada tahun 2013 dan proyeksinya sampai dengan 20 tahun mendatang (tahun 2033). Berdasarkan rasio pertumbuhan penduduknya, proyeksi jumlah penduduk per-kecamatan dapat dilihat pada Tabel 5. Kebutuhan air untuk domestik pada tahun-tahun proyeksi dapat dilihat pada Tabel 7. Peningkatan jumlah penduduk menyebabkan peningkatan terhadap kebutuhan air domestik.

Kebutuhan air untuk fasilitas pendidikan dari tahun ke tahun, proyeksi ini tergantung dari peningkatan jumlah muridnya dan jumlah hari masuk sekolah. Jumlah murid diproyeksikan dengan menggunakan rasio pertumbuhan penduduk setempat. Tabel proyeksi jumlah murid per kecamatan per tahun proyeksi dapat dilihat pada Tabel 4. Kebutuhan airnya pada tahuntahun proyeksi dapat dilihat pada Tabel 5. Peningkatan jumlah murid menyebabkan peningkatan kebutuhan air konsumsinya.

Kebutuhan air untuk fasilitas kesehatan tergantung dari jumlah puskesmas dan tempat tidur dari rumah sakit atau klinik. Terdapat 34 unit puskesmas dan 850 tempat tidur dari 34 rumah sakit/klinik. Jumlah tersebut diasumsikan konstan sampai tahun 2033. Proyeksi kebutuhan airnya dapat dilihat pada Tabel 5. 
Tabel 4

Proyeksi Jumlah Murid Per Tahun Proyeksi di DAS Keduang

\begin{tabular}{|c|c|c|c|c|c|c|c|c|c|c|c|}
\hline \multirow{3}{*}{\multicolumn{2}{|c|}{ 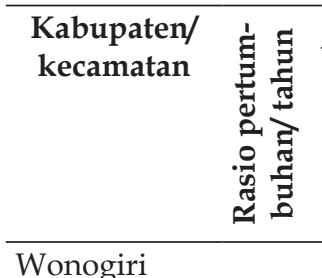 }} & \multicolumn{10}{|c|}{ Proyeksi jumlah penduduk dan murid pada tahun-tahun proyeksi } \\
\hline & & \multicolumn{2}{|c|}{2013} & \multicolumn{2}{|c|}{2018} & \multicolumn{2}{|c|}{2023} & \multicolumn{2}{|c|}{2028} & \multicolumn{2}{|c|}{2033} \\
\hline & & $\mathrm{P}^{*}$ & $M^{*}$ & $\mathrm{P}^{*}$ & $M^{*}$ & $\mathrm{P}^{*}$ & $\mathrm{M}^{*}$ & $\mathrm{P}^{*}$ & $M^{*}$ & $\mathrm{P}^{*}$ & $M^{*}$ \\
\hline Slogohimo & 0,004 & 41,034 & 7.153 & 41,879 & 7.300 & 42,741 & 7.450 & 43,621 & 7.604 & 44,520 & 7.761 \\
\hline Jatipurno & 0,004 & 31,126 & 6.148 & 31,768 & 6.275 & 32,423 & 6.404 & 33,092 & 6.536 & 33,774 & 6.671 \\
\hline Jatisrono & 0,004 & 56,914 & 10.673 & 58,084 & 10.893 & 59,279 & 11.117 & 60,498 & 11.345 & 61,742 & 11.579 \\
\hline Jatiroto & 0,004 & 33,569 & 5.481 & 34,260 & 5.594 & 34,965 & 5.709 & 35,685 & 5.827 & 36,420 & 5.946 \\
\hline Girimarto & 0,004 & 30,503 & 3.977 & 31,130 & 4.059 & 31,770 & 4.142 & 32,424 & 4.228 & 33,091 & 4.315 \\
\hline Sidoharjo & 0,007 & 33,118 & 6.215 & 34,273 & 6.432 & 35,468 & 6.656 & 36,705 & 6.888 & 37,986 & 7.128 \\
\hline Ngadirojo & 0,004 & 35,089 & 4.992 & 35,811 & 5.095 & 36,548 & 5.199 & 37,301 & 5.307 & 38,069 & 5.416 \\
\hline $\begin{array}{l}\text { Nguntoro- } \\
\text { nadi }\end{array}$ & 0,004 & 2,026 & 181 & 2,067 & 185 & 2,110 & 189 & 2,154 & 192 & 2,198 & 197 \\
\hline Wonogiri & 0,004 & 4,791 & 565 & 4,894 & 577 & 4,999 & 590 & 5,107 & 602 & 5,217 & 615 \\
\hline Karanganyar & & 11,337 & 1.235 & 12,148 & 1.324 & 13,017 & 1.418 & 13,949 & 1.520 & 14,947 & 1.628 \\
\hline Jatiyoso & 0,014 & & & & & & & & & & \\
\hline Total & & 279,507 & 46.620 & 286,317 & 47.732 & 293,326 & 48.874 & 300,540 & 50.049 & 307,969 & 51.256 \\
\hline
\end{tabular}

Keterangan: $P=$ jumlah penduduk (jiwa) dan $\mathrm{M}=$ jumlah murid (jiwa)

Kebutuhan air untuk fasilitas peribadatan dihitung berdasarkan jumlah masjid dan mushola yang mempergunakan air dalam ritual ibadahnya. Jumlah masjid sebanyak 665 unit dan mushola sebanyak 245 unit. Asumsi untuk proyeksi jumlahnya adalah bahwa masing-masing masjid dan mushola bertambah satu unit per lima tahun, sehingga setiap lima tahun ke depan kebutuhan airnya meningkat. Kebutuhan airnya pada tahuntahun proyeksi dapat dilihat pada Tabel 5.

Kebutuhan air untuk fasilitas perkantoran dihitung berdasarkan jumlah pegawai dan hari masuk kerja. Perkantoran yang dimaksud meliputi kantor kecamatan, kelurahan/balai desa, dan kantor pemerintahan lainnya. Jumlah pegawai diasumsikan sama dari tahun ke tahun, yaitu sebanyak 1.288 orang, sehingga kebutuhan air untuk fasilitas perkantoran adalah sama pada tahun-tahun proyeksi (Tabel 5).

Kebutuhan air untuk industri, pasar, dan pertokoan dihitung berdasarkan jumlah pegawai dan hari masuk kerja untuk industri dan pertokoan, luas pasar untuk fasilitas pasar, dan jumlah kursi untuk warung makan. Jumlah toko dan warung diasumsikan bertambah 1 unit per-kecamatan per tahun. Jumlah toko sebanyak176 unit dan warung makan sebanyak 8 unit. Jumlah pegawai industri sebanyak 40 orang dari empat unit industri dan luas pasar seluas $29.647 \mathrm{~m}^{2}$ diasumsikan konstan hingga tahun 2013. Proyeksi kebutuhan airnya dapat dilihat pada Tabel 5 .

Kebutuhan air untuk peternakan dihitung berdasarkan jumlah masing-masing jenis hewan yang diasumsikan konstan sampai tahun 2013. Asumsi jumlah masingmasing jenis hewan yang konstan didasarkan pada data jumlah masing-masing jenis hewan yang hampir tidak berubah dari tahun ke tahun menurut sensus BPS. Jumlah masingmasing jenis ternak adalah 38.852 ekor sapi/ kerbau, 88.925 ekor kambing/ domba, 4.049 ekor babi, dan 596.130 ekor unggas, sehingga kebutuhan air pada tahun-tahun proyeksi adalah sama (Tabel 5).

Kebutuhan air untuk irigasi dihitung berdasarkan luas sawah yang diproyeksikan dengan rasio penambahan luas sebesar $0,49 \%$ pertahun. Dasar perhitungan rasio penambahan luas adalah hasil dari perhitungan rata-rata penambahan luas sawah berdasarkan data spasial. Kebutuhan air pada tahun-tahun proyeksi secara berurutan dapat dilihat pada Tabel 5. 
Kebutuhan air total yang meliputi kebutuhan air untuk domestik, fasilitas kesehatan, pendidikan, peribadatan, perkantoran, industri, pasar, pertokoan, dan peternakan, serta irigasi pada tahun-tahun proyeksi. Secara berurutan adalah 81.063.567,42 $\mathrm{m}^{3} /$ tahun, $97.349 .296 .44 \mathrm{~m}^{3}$ / tahun, 115.306.529.35 $\mathrm{m}^{3} /$ tahun, 133.261.053.42 $\mathrm{m}^{3} /$ tahun, 151.227. $646.97 \mathrm{~m}^{3} /$ tahun.

Tabel 5

Hasil Perhitungan Kebutuhan Air $\left(\mathrm{m}^{3} /\right.$ tahun) Pada Tahun-Tahun Proyeksi

\begin{tabular}{|c|c|c|c|c|c|c|}
\hline \multirow[t]{2}{*}{ No } & \multirow{2}{*}{$\begin{array}{c}\text { Jenis kebutuhan } \\
\text { air }\end{array}$} & \multicolumn{5}{|c|}{ Tahun proyeksi } \\
\hline & & 2013 & 2018 & 2023 & 2028 & 2033 \\
\hline 1 & Domestik & $6.121 .203,30$ & $6.270 .351,58$ & $6.423 .840,17$ & $6.581 .835,95$ & $6.744 .514,27$ \\
\hline 2 & Perkantoran & $3.181,36$ & $3.181,36$ & $3.181,36$ & $3.181,36$ & $3.181,36$ \\
\hline 3 & Fasilitas Kesehatan & $113.150,00$ & $113.150,00$ & $113.150,00$ & $113.150,00$ & $113.150,00$ \\
\hline 4 & Fasilitas Pendidikan & $124.009,20$ & $126.967,58$ & $130.007,13$ & $133.130,66$ & $136.341,12$ \\
\hline 5 & Fasilitas Peribadatan & $907.755,00$ & $926.005,00$ & $944.255,00$ & $962.505,00$ & $980.755,00$ \\
\hline 6 & Peternakan & $868.947,11$ & $868.947,11$ & $868.947,11$ & $868.947,11$ & $868.947,11$ \\
\hline 7 & $\begin{array}{l}\text { Industri, Pasar, } \\
\text { dan pertokoan }\end{array}$ & $24.634,14$ & $142.990,29$ & $150.363,29$ & $150.436,29$ & $157.809,29$ \\
\hline 8 & Irigasi & $72.900 .687,32$ & $88.897 .703,53$ & $106.672 .785,30$ & $124.447 .867,06$ & $142.222 .948,82$ \\
\hline & Total & $81.063 .567,42$ & $97.349 .296,44$ & $115.306 .529,35$ & $133.261 .053,42$ & $151.227 .646,97$ \\
\hline
\end{tabular}

\section{Ketersediaan Air}

Kelompok hidrologi tanah dan luas lahannya ditentukan dengan menumpang tindihkan peta jenis tanah, peta penggunaan lahan, dan peta lahan kritis. Penggunaan lahan yang terklasifikasi dalam peta sebanyak lima jenis penggunaan lahan, yaitu tegalan, sawah, pemukiman, padang rumput, dan hutan. DAS Keduang mempunyai luas 42.098,07 ha dengan jenis penggunaan lahan meliputi hutan seluas $1.557,22$ ha $(3,70 \%)$, padang rumput seluas $1.508,27$ ha $(3,58 \%)$, perairan darat seluas 143,87 ha $(0,34 \%)$, pemukiman seluas $9.529,98$ ha $(22,64 \%)$, sawah seluas $6.859,82$ ha $(16,29 \%)$, dan tegalan seluas $22.498,90$ ha $(53,44 \%)$.



Gambar 1

Penggunaan Lahan Tahun 2013
Hasil tumpang tindih tersebut menunjukkan bahwa jenis hidrologi tanah di DAS Keduang masuk dalam kelompok A $(9.476,74$ ha) dan $\mathrm{D}$ (32.621,33 ha), sehingga $\mathrm{CN}$ yang dipergunakan adalah $\mathrm{CN}$ komposit. Menurut Asdak (2007) kelompok A mempunyai kriteria, di mana potensi air larian paling kecil, termasuk tanah pasir dalam dengan unsur debu dan liat, serta laju infiltrasinya tinggi, sedangkan kelompok D mempunyai kriteria di mana potensi air larian tinggi, kebanyakan tanah liat, dangkal dengan lapisan kedap air dekat permukaan tanah, dan laju infiltrasinya rendah. Berdasarkan kriteria hidrologi tanah dan jenis tanah di DAS Keduang, kelompok A terdiri atas jenis tanah litosol, sedangkan kelompok B terdiri atas jenis tanah latosol dan meteran.

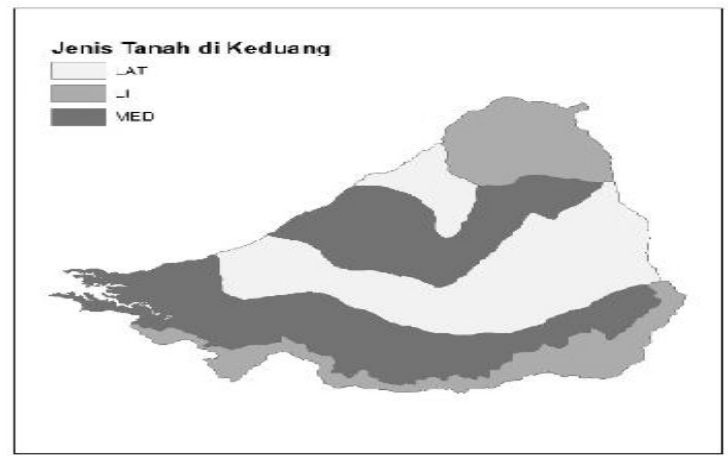

Gambar 2

Jenis Tanah di Keduang 
Sebelum CN ditentukan, AMC ditentukan terlebih dahulu dengan menghitung jumlah hujan selama lima hari terdahulu $\left(\mathrm{API}_{5}\right)$ yang ditentukan dari peristiwa banjir pada 25 Desember 2004 dan sebesar 31,62 mm, sehingga DAS Keduang masuk dalam AMC I (kondisi kering).

Tabel 6

CN yang Dipergunakan Dalam Perhitungan

\begin{tabular}{|c|c|c|c|c|c|c|}
\hline \multirow{2}{*}{ No } & \multirow{2}{*}{ Penggunaan lahan } & \multirow{2}{*}{ Kondisi hidrologi tanah } & \multicolumn{2}{|c|}{ kelompok tanah $\mathrm{A}$} & \multicolumn{2}{|c|}{ kelompok tanah D } \\
\hline & & & CN (II) & CN (I) & CN (II) & CN (I) \\
\hline 1 & Tegalan & & 45 & 25,58 & 83 & 67,22 \\
\hline \multirow[t]{2}{*}{2} & \multirow[t]{2}{*}{ Sawah } & Buruk & 63 & 41,70 & 85 & 70,41 \\
\hline & & Baik & 61 & 39,64 & 85 & 70,41 \\
\hline 3 & Pemukiman & & 57 & 35,77 & 86 & 72,07 \\
\hline \multirow[t]{3}{*}{4} & \multirow[t]{3}{*}{ Padang rumput } & Buruk & 68 & 47,16 & 89 & 77,26 \\
\hline & & Sedang & 49 & 28,75 & 84 & 68,80 \\
\hline & & Baik & 39 & 21,17 & 80 & 62,69 \\
\hline \multirow[t]{3}{*}{5} & \multirow[t]{3}{*}{ Hutan } & Buruk & 45 & 25,58 & 83 & 67,22 \\
\hline & & Sedang & 36 & 19,11 & 79 & 61,24 \\
\hline & & Baik & 25 & 12,29 & 77 & 58,44 \\
\hline 6 & Perairan darat & & 0 & 0 & 0 & 0 \\
\hline
\end{tabular}

Proyeksi luas penggunaan lahan dihitung berdasarkan rasio penambahan pertahun dari masing-masing jenis penggunaan lahan (Tabel 7), sedangkan perhitungan hasil air total dapat dilihat pada Tabel 8. Prediksi hasil air total semakin menurun dari tahun ke tahun. Hal ini disebabkan oleh adanya perubahan penggunaan lahan yang mempengaruhi $\mathrm{CN}$ - nya. CN menggambarkan hubungan antara volume debit (limpasan) dengan sifat DAS, seperti tipe tanah, tanaman penutup, tata guna lahan, dan kelembaban tanah (Putri, 2014). Semakin besar nilai $C N$, semakin kecil jumlah air resapan atau terinfiltrasi, semakin besar debit permukaannya, dan semakin kecil hasil air totalnya.

Tabel 7

Proyeksi Luas Penggunaan Lahan Pada Tahun-Tahun Proyeksi

\begin{tabular}{|c|c|c|c|c|c|c|c|c|}
\hline \multirow[t]{2}{*}{ No } & \multirow{2}{*}{$\begin{array}{c}\text { Jenis } \\
\text { penggunaan } \\
\text { lahan }\end{array}$} & \multirow{2}{*}{$\begin{array}{c}\text { Kelompok } \\
\text { hidrologi } \\
\text { tanah }\end{array}$} & \multirow{2}{*}{$\begin{array}{c}\text { Rasio } \\
\text { penambahan } \\
\text { per tahun }\end{array}$} & \multicolumn{5}{|c|}{ Tahun proyeksi } \\
\hline & & & & 2013 & 2018 & 2023 & 2028 & 2033 \\
\hline \multirow[t]{2}{*}{1} & \multirow{2}{*}{$\begin{array}{l}\text { Padang } \\
\text { Rumput }\end{array}$} & $\mathrm{A}$ & $(0,04)$ & $1.397,45$ & $1.090,89$ & 673,52 & 256,15 & 0 \\
\hline & & $\mathrm{D}$ & $(0,16)$ & 110,82 & 0 & 0 & 0 & 0 \\
\hline \multirow[t]{2}{*}{2} & \multirow{2}{*}{$\begin{array}{l}\text { Perairan } \\
\text { Darat }\end{array}$} & $\mathrm{A}$ & 0 & 0 & 0 & 0 & 0 & 0 \\
\hline & & $\mathrm{D}$ & $(0,01)$ & 143,87 & 125,55 & 107,22 & 88,89 & 70,60 \\
\hline \multirow[t]{2}{*}{3} & \multirow[t]{2}{*}{ Pemukiman } & $\mathrm{A}$ & 0,001 & 853,88 & 855,06 & 856,24 & 857,42 & 858,59 \\
\hline & & $\mathrm{D}$ & $(0,62)$ & $8.831,67$ & $7.522,45$ & $6.213,24$ & $4.904,02$ & $3.594,80$ \\
\hline \multirow[t]{2}{*}{4} & \multirow[t]{2}{*}{ Tegalan } & $\mathrm{A}$ & $(0,19)$ & $4.772,70$ & $4.379,94$ & $3.987,18$ & $3.594,42$ & $3.040,39$ \\
\hline & & $\mathrm{D}$ & 0,11 & $17.570,64$ & $17.806,36$ & $18.042,07$ & $18.277,79$ & $18.513,51$ \\
\hline \multirow[t]{2}{*}{5} & \multirow[t]{2}{*}{ Sawah } & $\mathrm{A}$ & 0,13 & 898,45 & $1.178,96$ & $1.459,46$ & $1.739,97$ & $2.020,48$ \\
\hline & & $\mathrm{D}$ & 0,68 & $5.961,37$ & $7.395,28$ & $8.829,18$ & $10.263,09$ & $11.697,00$ \\
\hline \multirow[t]{3}{*}{6} & \multirow[t]{2}{*}{ Hutan } & $\mathrm{A}$ & 0,09 & $1.554,27$ & $1.743,59$ & $1.929,96$ & $2.116,33$ & $2.302,70$ \\
\hline & & $\mathrm{D}$ & $(0,002)$ & 2,95 & 0 & 0 & 0 & 0 \\
\hline & Total & & & $42.098,07$ & $42.098,07$ & $42.098,07$ & $42.098,07$ & $42.098,07$ \\
\hline
\end{tabular}


ERLYNDA KUMALAJATI, SAMBAS SABARNUDI, BUDIADI, DAN PUTU SUDIRA ANALISIS

KEBUTUHAN DAN KETERSEDIAAN AIR DI DAS KEDUANG JAWA TENGAH

Tabel 8

Proyeksi Luas Penggunaan Lahan Pada Tahun-Tahun Proyeksi

\begin{tabular}{|c|c|c|c|c|c|}
\hline No & Kondisi penggunaan lahan & CN komposit & $\mathrm{S}(\mathrm{mm})$ & $\mathrm{Q}(\mathrm{mm})$ & Hasil total air (m³/tahun) \\
\hline 1 & Model (2004) & 59,93 & 169,86 & 98,79 & $113.094 .161 .160,42$ \\
\hline 2 & $\begin{array}{l}\text { Kecenderungan I: aktual } \\
\text { (2013) }\end{array}$ & 59,89 & 170,12 & 98,68 & 113.156.693.217,77 \\
\hline 3 & Kecenderungan II : 2018 & 60,11 & 168,58 & 99,34 & $112.788 .992 .785,78$ \\
\hline 4 & Kecenderungan III: 2023 & 60,43 & 166,31 & 100,33 & 112.250.655.736,21 \\
\hline 5 & Kecenderungan IV: 2028 & 60,76 & 164,07 & 101,32 & $111.723 .216 .386,22$ \\
\hline 6 & Kecenderungan V: 2033 & 61,10 & 161,69 & 102,38 & 111.169.562.185,45 \\
\hline
\end{tabular}

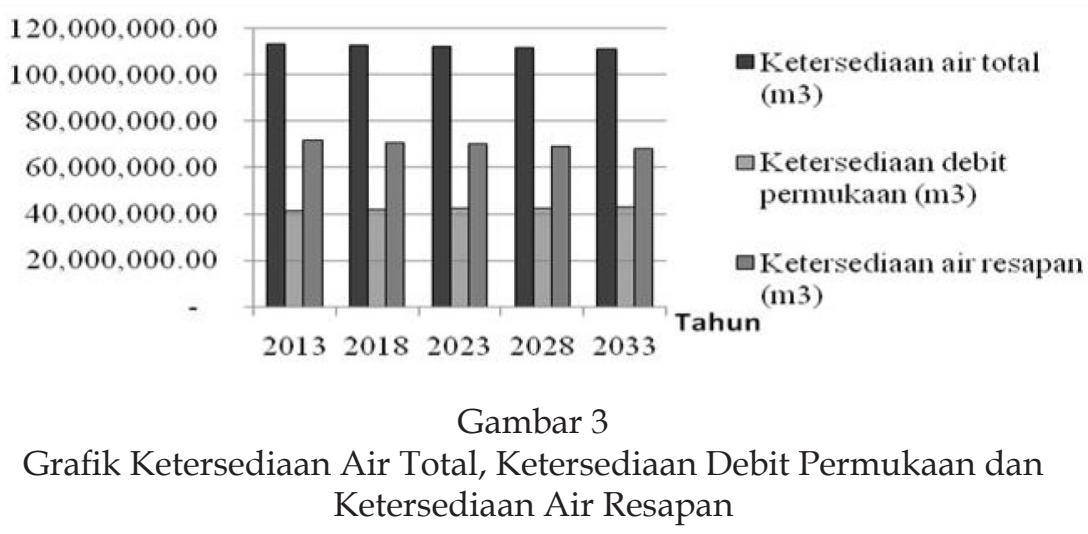

Faktor konversi lahan mempengaruhi hasil air DAS melalui perubahan CN-nya. Penambahan hutan tidak secara signifikan mampu menambah hasil air karena rasio penambahan per tahun hanya sebesar 0,09 untuk kelompok tanah A dengan kondisi hidrologi yang buruk mencapai 41,09\%. Di sisi lain, penambahan luas sawah cukup besar dengan rasio penambahan per tahun sebesar 0,13 untuk kelompok tanah A dan 0,68 untuk kelompok tanah D. Penambahan luasan sawah tersebut, secara signifikan menambah nilai $\mathrm{CN}$, sehingga mengurangi air resapan DAS.

\section{Neraca Air di DAS Keduang}

Perbandingan antara kebutuhan dan ketersediaan air menunjukkan hasil bahwa peningkatan kebutuhan air dari tahun ke tahun tidak diiringi oleh ketersediaan air di DAS Keduang, sehingga neraca airnya semakin menuju ke arah defisit air. Penurunan ketersediaan air disebabkan adanya perubahan penggunaan lahan yang menurunkan hasil air total melalui semakin besarnya $\mathrm{CN}$. Semakin besar $\mathrm{CN}$, semakin kecil tingkat resapannya karena $\mathrm{CN}$ berhubungan dengan sifat tanah, penggunaan lahan, dan kondisi hidrologi DAS (Putri, 2014). Dephut (1998; dalam Hastono dkk., 2012) menyatakan bahwa semakin besar tingkat resapan (infiltrasi), maka semakin kecil tingkat air larian (run off), sehingga debit banjir dapat menurun dan sebaliknya aliran dasar (base flow) dapat naik.

Peningkatan luas lahan sawah dan pemukiman pada kelompok hidrologi tanah D mempengaruhi secara signifikan peningkatan $\mathrm{CN}$ pada tahun-tahun proyeksi, terutama pada tahun 2033. Pengaruh pada peningkatan $\mathrm{CN}$ dicerminkan dari adanya penurunan hasil air total dan air terinfiltrasi dari tahun aktual dibandingkan dengan tahun-tahun proyeksi. Penurunan hasil air total dan air terinfiltrasi, secara berurutan sebesar 1.991.238,53 $\mathrm{m}^{3} /$ tahun dan $3.548 .866,97 \mathrm{~m}^{3} /$ tahun dari tahun aktual sampai dengan tahun 2033.

Seiring dengan penurunan ketersediaan air, kebutuhan air semakin meningkat sebagai konsekuensi dari bertambahnya 
penduduk. Defisit air mulai terlihat pada tahun 2023 dan semakin besar pada tahuntahun proyeksi berikutnya (lihat gambar 4). Defisit terbesar akan terjadi pada tahun 2033 apabila kecenderungan perubahan penggunaan lahan saat ini tidak dihentikan dan tidak diarahkan menuju perubahan yang bisa memperbaiki kondisi hidrologi DAS menuju konservasi air DAS.

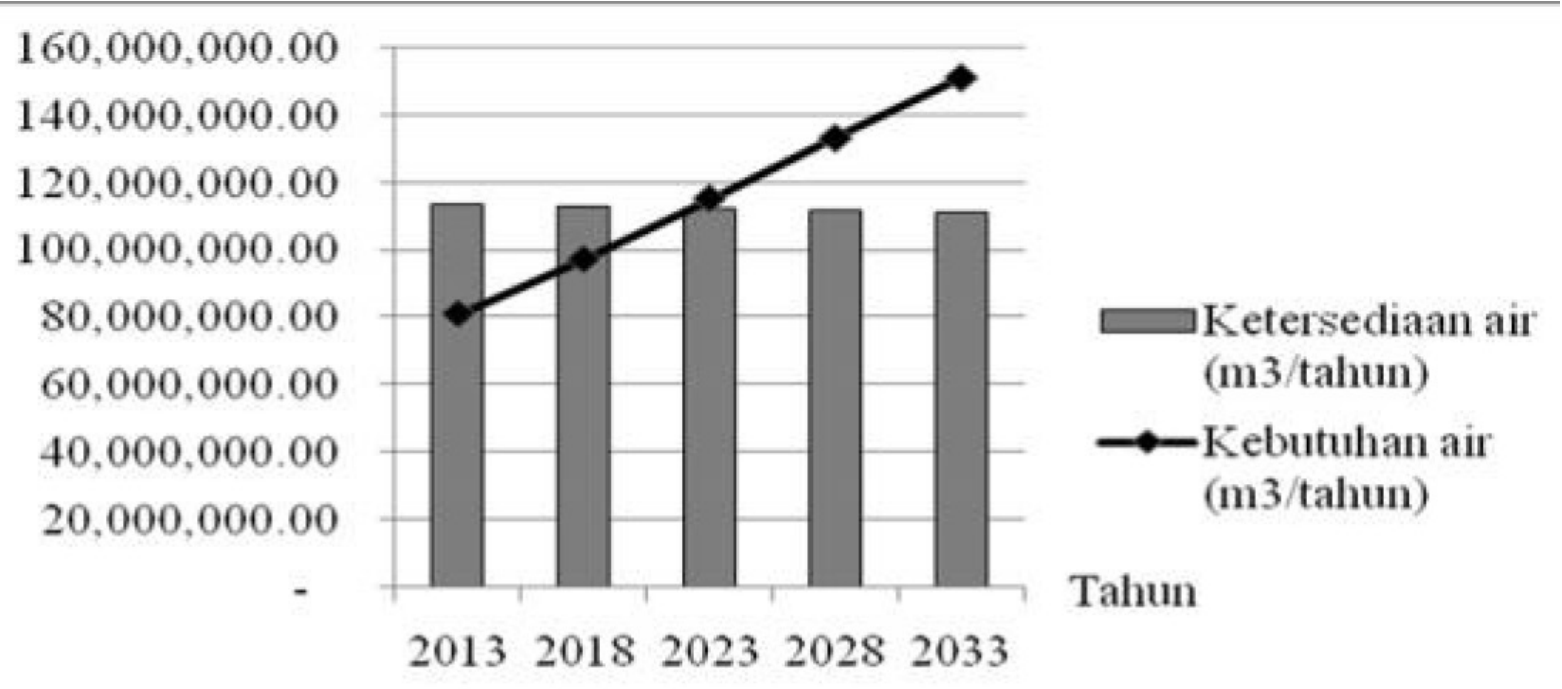

Gambar 4

Neraca Air DAS Keduang dari Tahun 2013 Sampai Dengan 2033

\section{SIMPULAN}

Kebutuhan air di DAS Keduang semakin bertambah dari tahun ke tahun dengan rata-rata penambahan 3,38\% per tahun, sedangkan ketersediaan airnya semakin berkurang dengan rata-rata pengurangan $0,09 \%$ per-tahun. Peningkatan kebutuhan air disebabkan oleh peningkatan jumlah penduduk dari tahun ke tahun, sedangkan penurunan ketersediaan airnya disebabkan oleh penurunan air terinfiltrasi yang dipengaruhi oleh kecenderungan perubahan penutupan lahan yang terjadi. Defisit air mulai terjadi pada tahun 2023 di mana kebutuhan air mencapai 115.306.568,00 $\mathrm{m}^{3}$ /tahun, sedangkan ketersediaan air hanya sebesar 112.250.656,00 $\mathrm{m}^{3} /$ tahun. Mengubah arah perubahan lahan dari kecenderungan saat ini menjadi perubahan yang bersifat konservatif terhadap air perlu dilakukan untuk mengantisipasi defisit air yang akan terjadi di masa depan.

\section{DAFTAR PUSTAKA}

Asdak, C. 2007. Hidrologi dan pengelolaan daerah aliran sungai. Yogyakarta: Gadjah Mada University Press, Yogyakarta.

Badan Standardisasi Nasional. 2002. SNI 19-6728.1-2002: Penyusunan neraca sumber daya - Bagian 1: Sumber daya air spasial. Jakarta: Badan Standardisasi Nasional (BSN).

Dinas Pekerjaan Umum. 1996. Kriteria Perencanaan Ditjen Cipta Karya tahun 1996. Jakarta: Dinas PU.

Hastono, F. D., Sudarsono, B., dan Sasmito, B. 2010. "Identifikasi Daerah Resapan Air Dengan Sistem Informasi Geografis (Studi Kasus: Sub Das Keduang)." Jurnal geodesi UNDIP, 1:1.

Putri, R.S.W. 2014. "Uji validitas metode SCS CN untuk analisis volume limpasan." Tesis. Yogyakarta: Program Pascasarjana Fakultas Teknik UGM.

Sutrisno, Joko. 2011. “Evaluasi ekonomi konversi lahan pertanian ke non 
ERLYNDA KUMALAJATI, SAMBAS SABARNUDI, BUDIADI, DAN PUTU SUDIRA ANALISIS KEBUTUHAN DAN KETERSEDIAAN AIR DI DAS KEDUANG JAWA TENGAH

pertanian di daerah aliran sungai (DAS) waduk Wonogiri (studi kasus di wilayah sub DAS Keduang kabupaten Wonogiri)." Disertasi. Bogor: Institut Pertanian Bogor.

USDA. 1988. Urban Hydrology For Small Watersheds: TR-55. Washington, DC. 